\title{
EL BESTIARIO DEL HISTORIADOR: LAS BIOGRAFÍAS DE "MONSTRUOS" DE BENJAMÍN VICUÑA MACKENNA Y LA IDENTIDAD LIBERAL COMO UN BIEN EN DISPUTA
}

\begin{abstract}
Este trabajo identifica y analiza una conjunto heterogéneo de textos (libros, artículos de prensa, folletos, diarios personales) del historiador Benjamín Vicuña Mackenna, los cuales, si bien aluden a temáticas muy diversas, conforman una constelación de sentido marcada por el esfuerzo de apropiación de la identidad liberal, definida no en función de las disputas ideológicas con la Iglesia Católica y el Partido Conservador, sino con relación a la lucha por la libertad electoral y el ensanchamiento de la base de ejercicio de la soberanía popular, cualquiera fuera el signo político del gobierno en ejercicio. Para ello, indaga en obras de distintos periodos del historiador, así como en variados episodios de su biografía, con el propósito de contextualizar las circunstancias de producción de los textos de interés para el análisis.
\end{abstract}

Palabras clave: Historiografía, liberalismo, revolución.

This article identifies and analyzes a heterogeneous body of texts (books, press articles, pamphlets and personal diaries) authored by Chilean historian Benjamin Vicuña Mackenna. These texts form part of a single constellation of meaning characterized by the effort of appropriation of a liberal identity, although they concern different subjects and were intended for diverse readerships. This identity was not defined based on the disputes with the Catholic Church or by the Conservative Party. Instead identity was defined by taking into account the fight for electoral freedom and the democratizing effects of popular sovereignty. The article explores the works of Vicuña Mackenna and various episodes of his life to contextualize the circumstances of the texts analyzed.

Key words: Historiography, Liberalism, Revolution, Alterity.

Fecha de recepción: noviembre 2007

Fecha de aceptación: marzo 2008

Universidad Diego Portales, Instituto de Investigación en Ciencias Sociales, ICSO. Correo electrónico: manuel.vicuna@udp.cl 


\section{EL MONSTRUO Y EL HISTORIADOR: CRUCES BIOGRÁFICOS}

Para Benjamín Vicuña Mackenna, 1877 es el año de los monstruos morales. En esos meses, publica investigaciones sobre dos figuras que, a juicio suyo, representaban el mal radical, encarnaban lo abominable en la historia de Chile.

Historiador prolífico, a esa altura Vicuña Mackenna ya acumulaba una serie de biografías de hombres notables, próceres y "patriotas" individualizados como los auténticos protagonistas del proceso de la independencia y de la construcción de la república. Solo para hacerse una idea: entre 1856 y 1866 publicó textos en general voluminosos sobre las vidas de su abuelo Juan Mackenna, de los hermanos Carrera, de O’Higgins y San Martín, además de redactar la primera biografía bien documentada de Diego Portales ${ }^{1}$. Al modo de Thomas Carlyle, lectura obligada de los historiadores del siglo XIX, ese ejercicio de discriminación respondía a unos criterios valorativos propios de los sectores dominantes ${ }^{2}$. A mediados de la década de 1870 , en cualquier caso, esa vocación ensalzadora experimenta un vuelco. En vez de documentar vidas eminentes con el objeto de formar un panteón de héroes nacionales, Vicuña Mackenna traza, entonces, los perfiles de los grandes malditos: Miguel José Cambiaso y Catalina de los Ríos, la Quintrala.

Cambiaso nunca gozó de la suerte póstuma de la Quintrala. Desde la Colonia hasta pleno siglo XIX, ella sobrevive bajo la forma de una leyenda popular, incluso de un mito urbano. A causa de Los Lisperguer y la Quintrala, cuya narrativa establece una matriz de la historia nacional de la infamia, la Quintrala dejó de ser una tradición oral. Mediatizada por el texto de Vicuña Mackenna, favorecido con varias ediciones, esa "hembra indómita, arrebatada y casi salvaje", derivó en un locus classicus del imaginario literario chileno, en una figura a la vez singular y arquetípica, material de sucesivas reelaboraciones novelescas, personaje vivo en el plano de la ficción y de la memoria histórica.

1 Concretamente: Vida del jeneral don Juan Mackenna, Santiago, Imprenta del Ferrocarril, 1856; El ostracismo de los Carrera. Los jenerales José Miguel y Juan José y el coronel Luis Carrera. Episodios de la independencia de Sud América, Santiago, Imprenta del Ferrocarril, 1857; El ostracismo del jeneral D. Bernardo O'Higgins, escrito sobre documentos inéditos i noticias auténticas, Valparaíso, Imprenta i Librería del Mercurio 1860; El jeneral don José de San Martín, considerado según documentos enteramente inéditos, con motivo de la inauguración de su estatua en Santiago el 5 de abril de 1863, Santiago, Imprenta Nacional, 1863; e Introducción a la historia de los diez años de la Administración Montt. D. Diego Portales, Valparaíso, Imprenta i Librería del Mercurio, 1863. La escritura histórica y en particular el género biográfico resultaron vehículos estratégicos de la pedagogía cívica en aras de la construcción cultural de la nación. Sobre la función social de la historia y el papel público de los historiadores en Chile e Iberoamérica durante el XIX, véase Gertrude Matyoka Yeager, "Barros Arana, Vicuña Mackenna, Amunátegui: The Historian as National Educator", Journal of Interamerican Studies and World Affairs, vol. 19, No 2 (1977), 173-200; y Nikita Harwich Vallenilla, "La Historia Patria", en Antonio Annino y François-Xavier Guerra, coord., Inventando la nación. Iberoamérica. Siglo XIX, México, FCE, 2003, 533-549.

2 Fritz Stern, ed., The Varieties of History from Voltaire to the Present [1956] New York, Vintage Books, 1973: "History as Biography: Carlyle", 90-107. Del elitismo de la historiografía latinoamericana del siglo XIX ha dado cuenta sobre la base de un estudio prosopográfico, E. Bradford Burns, "Ideology in Nineteenth-Century Latin American Historiography", The Hispanic American Historial Review, vol. 58, No 3 (1978), 409-431. 
Nada similar sucede con Cambiaso, el cabecilla de un sangriento motín en Punta Arenas, que le costó la vida, entre otras víctimas, al gobernador y al capellán de la colonia. Nacido hacia 1821, hijo de un médico o practicante español y de una chilena, ingresa al cuartel de Artillería de Santiago. Diestro en el trabajo burocrático y aficionado a la química, el joven recluta gana posiciones con facilidad. De este modo comienza una discreta carrera militar que concluiría, con gran revuelo de la opinión pública, en abril de 1852, luego de ser condenado a morir en un patíbulo levantado a la vista de una expectante multitud en Valparaíso, para luego ser descuartizado, torpemente, ante la mirada horrorizada de los espectadores, por la mano de un verdugo improvisado.

Durante años, Vicuña Mackenna reúne materiales sobre Cambiaso, demostrando un temprano interés en narrar ese episodio; para la elaboración del libro utiliza testimonios de testigos o protagonistas del motín, redactados a expresa petición suya, siempre ávido de documentos para su archivo personal, con bastante anterioridad a 1877. Pero solo entonces sucede algo que detona el proceso de escritura: un motín de artilleros en Punta Arenas. La composición del libro, lo dice Vicuña Mackenna, es la reacción en caliente ante las noticias de un suceso que parece la reiteración fatídica del levantamiento encabezado por Cambiaso ${ }^{3}$.

Debido a los vínculos entre ambos motines, la historia olvidada de Cambiaso cobra una actualidad insospechada. Traer a colación esa tragedia original, recurrente como un trauma, sirve para alertar sobre las consecuencias del drama en desarrollo, ayudando a conjurar la nefasta temporalidad circular que pone en riesgo el asentamiento chileno en el Estrecho de Magallanes. Escribir Cambiaso bajo la presión del levantamiento en curso implicaba un llamado de atención -a la fecha Vicuña Mackenna integraba el Senado- sobre la necesidad de modificar las condiciones objetivas de la colonia. No enmendar la situación era exponerse a la periódica resurrección del "alma de Cambiaso". Vicuña Mackenna redacta el libro con el apremio propio de una emergencia, en ocho días de arrebato, instigado por las noticias del motín de los Artilleros, al ritmo sincopado de las "revelaciones palpitantes del telégrafo"4.

Con ese fin, Vicuña Mackenna narra la historia de los intentos por asentar la soberanía nacional en Magallanes y consumar, así, la integridad territorial del Estado. Los intereses en juego resultan evidentes: el Estrecho de Magallanes representaba una ruta de creciente valor estratégico, dado el ímpetu del comercio mundial asociado a la navegación a vapor. Previo a la entrada de Cambiaso en escena, Vicuña Mackenna relata las vicisitudes de esa colonia austral, especificando sus características, al margen de sus distintas locaciones geográficas, inicialmente en Fuerte Bulnes y, más tarde, en Punta Arenas. Descontando las inclemencias del medio, la precariedad del abastecimiento, las penalidades de una comunidad aisla-

3 Sobre la sublevación de 1877, véase Armando Braun Menéndez, El motín de los artilleros [1934] Buenos Aires, Editorial Francisco de Aguirre, 1972.

4 Benjamín Vicuña Mackenna, Cambiaso. Relación de los acontecimientos i de los crímenes de Magallanes en 1851 escrita sobre numerosos documentos inéditos Santiago, Imp. de la Librería del Mercurio, 1877, v. 
da, ese enclave humano presenta peligros estructurales. Mezcla laxa de guarnición militar y colonia penal para delincuentes comunes, prisioneros políticos y desertores del ejército, es un lugar de expiación no solo para los desterrados, sino también, en parte, para la oficialidad y la tropa destinada a custodiarlos.

Significativamente, el primer "mando superior" de la colonia fue confiado a un "viejo pipiolo dado de baja en Lircay, i cuya promoción a Magallanes casi no fue ni una rehabilitación ni un ascenso: tal era el horror que inspiraban aquellos lugares apenas conocidos, i que se suponían, por la imajinación popular, un simple apéndice del polo"5. En Magallanes, todos comparten unas condiciones de vida extremas; la distinción entre militares o colonos y confinados es tenue, porosa hasta la imprudencia. A Magallanes se envía a la "parte más ruin" de la tropa, al desecho del ejército; esa destinación resulta un "verdadero castigo", un castigo agravado por la ausencia de una política de relevos. Soldados y confinados (muchos de ellos, ex soldados, ex compañeros) padecen un destino común; de esa identidad forzosa no cabía esperar nada bueno; el relajamiento de la disciplina y la temeridad proclive a la revuelta son frutos estacionales llamados a madurar tarde o temprano. "Condenar a un soldado a la misma inmovilidad de los presidiarios que custodia, es casi condenarlo a su propio castigo i, de seguro, a sus propios vicios" .

Dada la naturaleza de este cuadro escénico, que Vicuña Mackenna dispone con sentido dramático, Cambiaso será presentado como el detonador casual que percuta el estallido de violencia en un arma ya cargada por el descuido del gobierno. "Jamás la mano de la ciega imprevisión había acumulado en un solo sitio, sin amparo ni socorro humano, tantos elementos para producir una de las más horribles catástrofes consignadas en los anales de la depravación humana". Remata: "Faltaba solo el soplo de un jenio maléfico para que aquella pira ardiese en el desierto, iluminando con sus rojas llamaradas la figura del monstruo abominable que se llamó Miguel José Cambiaso"7.

Previsiblemente, Cambiaso participa de la "ilusión biográfica" identificada por el sociólogo Pierre Bourdieu. Es decir, le otorga al relato de una vida la coherencia de una trayectoria, de un itinerario capaz de supeditar el embrollo de la experiencia y la arbitrariedad de los recuerdos a un sentido global ${ }^{8}$. Esa "ilusión biográfica", que supone un yo inmune a las fluctuaciones aleatorias de la contingencia, sigue permeando la novela realista, el género biográfico, la autobiografía y la investigación antropológica traducida al formato de las "historias de vida".

Por fuerza inmerso en ese universo discursivo, el único posible para un historiador de su tiempo, Vicuña Mackenna elabora un relato que, con presunciones de

$5 \quad$ Ibid., 15. Apoyándose en una base documental más sólida, si bien reproduciendo los patrones interpretativos de Vicuña Mackenna, la historia criminal de Cambiaso volvería a ser contada, casi un siglo después de su versión original, por Armando Braun Menéndez, Cambiazo. El último pirata del Estrecho. Buenos Aires, Editorial Francisco de Aguirre, 1971.

6 Vicuña Mackenna, Cambiaso, 47.

7 Ibid., 53.

8 Pierre Bourdieu, Razones prácticas. Sobre la teoría de la acción [1997], Barcelona, Editorial Anagrama, 2002, 74-83. 
objetividad, opera como los antiguos peritajes psiquiátricos ${ }^{9}$. A partir de hechos puntuales, amén de punibles, interpreta toda la vida del acusado, teñida así, retrospectivamente, por unos actos anómalos tardíos. La escena del crimen y el tiempo de la infracción se convierten en lugar y momento de la aparición casi epifánica de la verdad del sujeto; el extravío, en vez de interpretarse como derrape en el curso de la vida, indica la ruta al sentido totalizante de la existencia. Del crimen se desprende la identidad del agente y, por ese deslizamiento involutivo, se proyecta una manera de ser remisible a las etapas vitales más tempranas. Esta identidad indica que el individuo estaba predestinado a la realización del delito; ahora el origen de este se localiza más allá del acto mismo y de su esfera inmediata de referencia: en los antecedentes familiares, en la niñez, en la adolescencia, en el carácter mismo.

Por eso, Vicuña Mackenna, antes de narrar las atrocidades cometidas durante el reinado de Cambiaso, hurga en su pasado, remontándose, tal como disponen las convenciones del género biográfico, lo más atrás posible. ¿Qué encuentra? Un prontuario: raptos de mujeres; el aparente conato de envenenamiento de su esposa; y la expulsión transitoria del servicio de las armas, por mala conducta. Conclusión: Cambiaso era un monstruo -inequívoca pero larvadamente- antes de manifestarse como tal. Vicuña Mackenna, aunque reserva páginas al intento de evidenciar la formación del monstruo a partir de la presión del entorno y las circunstancias, por influjo de factores externos, finalmente privilegia la lógica de su peritaje histórico: Cambiaso es monstruo por naturaleza, con abstracción de los condicionamientos del medio. Si, por un momento, cree haber identificado un episodio y unos incidentes que habrían incubado al monstruo, a la larga pesa más, como síntesis del heterogéneo compuesto del libro, esta sentencia drástica: de "lodo sangriento [...]

9 Efectivamente, en la obra de Vicuña Mackenna solo cabe hablar de "presunciones de objetividad". Vicuña Mackenna, como buena parte de los historiadores chilenos de la segunda mitad del siglo XIX, rindió pleitesía al discurso del método formulado por Andrés Bello en la década de 1840, a raíz de la célebre polémica con José Victorino Lastarria, discurso patrocinado oficialmente a través de la Universidad de Chile, con motivo de las memorias anuales sobre la historia nacional leídas en sesión solemne. En general, los prólogos de los libros de Vicuña Mackenna dan cuenta de esta profesión de fe positivista, que exalta el valor referencial de los documentos y alega para el historiador el papel de mediador objetivo de una verdad corroborada por testimonios inapelables. Otra cosa, sin embargo, ocurre en sus libros pasado el umbral del prólogo: Vicuña Mackenna viola de manera sistemática y ostentosa las prevenciones empíricas del método de Bello, del todo opuesto a las sistemáticas licencias interpretativas y a las incursiones ficcionales del presunto discípulo. Un libro como Cambiaso -sin ser una excepción a la regla- ilustra eso de manera flagrante. De ahí mis discrepancias con la inclusión de Vicuña Mackenna en el grupo de los "grandes historiadores positivistas", tal como lo hace Cristián Gazmuri R., La historiografía chilena (1842-1970), tomo I: (1842-1920), Taurus y Centro de Investigaciones Diego Barros Arana, Santiago, 2006. Sobre la constitución de la historiografía chilena a partir del célebre debate entre Bello y Lastarria, y sobre las claudicaciones de la voluntad de objetividad a las pasiones ideológicas del día, véase Allen Woll, A Functional Past. The Uses of History in Nineteenth-Century Chile, Baton Rouge and London, Louisiana State University Press,1982; e Iván Jaksic A., Andrés Bello: La pasión por el orden, Santiago, Editorial Universitaria, 2001, 163-174. Ese célebre debate fundacional del campo historiográfico chileno tuvo su correlato en la Argentina, con la polémica muy posterior entre Bartolomé Mitre y Vicente Fidel López. Sobre el particular, véase Roberto Madero, La historiografía entre la República y la Nación. El caso de Vicente Fidel López, Buenos Aires, Catálogos, 2005. 
había sido amasada su alma". Al referir el proceso criminal de Cambiaso y su corolario, la condena a muerte, Vicuña Mackenna sostendrá que el cadalso "era su destino quizá desde la cuna" ${ }^{10}$.

Todo estalla en noviembre de 1851, el día 21. Cambiaso, enemistado con su capitán, lo amenaza de muerte, desenvainando su espada; sumariado, es recluido en una cuadra; allí, resentido, ambiciona la revancha; unos ex sargentos recién confinados a causa del levantamiento antigobiernista del batallón Valdivia (ocurrido el 20 de abril en Santiago), traman sublevar la guarnición para regresar al teatro de la guerra civil recién desatada (de hecho, con ellos arribó esa noticia a Magallanes); sin jefe, invitan a Cambiaso a liderar la revuelta; para tentarlo, le animan con la idea de vengarse a voluntad del capitán Salas, su bestia negra. Debido a la pusilanimidad del gobernador, el motín es un éxito; y Cambiaso queda a cargo de la situación. Haciendo gala de su rigor, no tarda en reclamar su primera víctima, un hombre de sus filas, del cual recela. "Desde el más osado de los jefes de la guarnición hasta el más vil de los presidiarios, todos se inclinarían en adelante, sumisos i respetuosos, en presencia del joven-monstruo que comenzaba a levantar la cabeza de uno de los más famosos criminales de la historia, en un apartado rincón de los mares australes, vecino de los polos, i para el cual la horca i la hoguera serían solo un simple accesorio de su engrandecimiento en el mal i en el exterminio frío i sistemático de sus semejantes"11. Con esta obertura macabra, Vicuña Mackenna entra en materia, relatando las particularidades de esa tiranía breve pero intensa.

Sin demora, Cambiaso organiza su ejército, con Estado Mayor y todo, declarando que se "proponía invadir las costas del Pacífico" para sumarse, con sus fuerzas revolucionarias, a las "tropas del jeneral Cruz", bajo cuya invocación se desenvuelve el servicio de armas de sus hombres ${ }^{12}$. Al frente de ex soldados relegados por su asonada contra el poder excesivo del Ejecutivo, de este modo Cambiaso le infundía visos de legitimidad política a la sublevación en curso. Dotado de una escolta personal, se aplica a otorgarle a su fuerza el método y el relumbre de un ejército en regla, con su respectivo libro de órdenes y proclamas, ejemplo de unas prácticas burocráticas orientadas a dejar registro formal de las disposiciones de la nueva comandancia. Instrucciones oficiales estimulan la delación y la vigilancia recíproca, mientras Cambiaso, afecto a las exterioridades del mando y a los goces del gasto simbólico, dispone medidas para instaurar un "aparato escénico" adecuado a las ínfulas del nuevo poder. En lugar de rendirle honores a la bandera nacional, se crea otra, una verdadera provocación al orden civilizado: un lienzo rojo con una cruz blanca en el centro que, al pie, luce un "cráneo engarzado entre dos tibias humanas, todo circundado por esta fanfarrona inscripción:-Conmigo no hai cuartel!- Según algunos testigos, el pendón de Cambiaso llevaba en el reverso este lema tan brutal como infame: -Soi pirata en el mar i salteador en tierra!"13.

\footnotetext{
10 Vicuña Mackenna, Cambiaso, 60 y 237, respectivamente.

11 Ibid., 84

12 Ibid., 85

13 Ibid., 96
} 
Cambiaso perturba la colonia con soplos de insania. Gusta mandar arrojar a la hoguera los cadáveres de sus víctimas, después de ordenar su fusilamiento, negándoles el derecho a una sepultura cristiana; y, ocasionalmente, tal como pasó con los asesinatos del gobernador y de tres tripulantes extranjeros de dos buques mercantes (uno estadounidense, el otro inglés) capturados mediante ardides, improvisa rituales macabros. Testigos de la causa criminal seguida contra Cambiaso recordaran que ante el cuerpo del gobernador, mientras lo consumían las llamas, ordenó cantar la canción nacional. Así describe Vicuña Mackenna la lóbrega ceremonia que sucedió a su fusilamiento:

\begin{abstract}
"Forzoso es agregar, [...] aunque el alma i la pluma se resistan, que Cambiaso hizo reunir sus bandas al derredor del cadalso; que ordenó dar fresco pábulo a la hoguera; que dispuso tronase el cañón de los acostumbrados regocijos, i que entonando todos a una voz el himno ya tantas veces profanado de la patria ausente e insultada, hizo arrojar al fuego por dos soldados, cojiéndole de los brazos i las piernas i cimbrándolo en el aire, el cadáver de su jefe... I en seguida, sobre el rescoldo de sus cenizas, mandó que le asasen un ternero para la gula de su nocturna cena, para el deleite de su consuetudinario bacanal" 14 .
\end{abstract}

El cuerpo del capellán también asesinado, nadie ofreciéndose a cavar su tumba, habría quedado tirado en el cementerio, según la versión de Vicuña Mackenna; y ahí sería devorado por las "zorras del monte, que así fraternizaban con los chacales humanos de la colonia"15. Prisioneros de Cambiaso, a la hora de declarar en el proceso, refieren que este no desaprovechó la oportunidad de exponerlos a la contemplación de los cadáveres de sus víctimas, exhibidas colgando de un árbol, o ardiendo en la hoguera. De la causa criminal Cambiaso emerge como el "motor" del motín y sus secuelas.

No es del caso abundar en pormenores macabros; aquí lo relevante es señalar que Cambiaso perdería la lealtad de sus hombres de confianza, luego de revelar su propósito de huir a Europa (o bien a Brasil) con un cargamento de oro californiano hallado en uno de los barcos secuestrados, desatendiendo su promesa de dirigirse a las costas del norte, a "Arauco", para plegarse a la lucha contra la administración de Manuel Montt. El 15 de enero de 1852, quedó rehén de sus propios cómplices, y la ruta del barco dado a la fuga se invirtió, arribando más tarde a Ancud, en un momento en que las autoridades centrales ya estaban al corriente del motín y todas las provisiones del caso para la captura de los piratas habían sido tomadas. El 24 de febrero recalan en Valparaíso los cautivos; alertados, los porteños se agolpan en la playa para observar el desembarco de un personaje, a esas alturas, legendario.

14 Ibid., 148.

15 Ibid., 153. En el proceso criminal consta, sin embargo, que el cadáver del capellán fue enterrado, aunque solo gracias a los ruegos de algunos residentes de la colonia. Véase en el Archivo Nacional de Chile (ANCh), Fondos Varios 166, "Copia de la causa criminal seguida en Valparaíso contra el Teniente Don Miguel José Cambiazo i sus cómplices, por la revolucion que hicieron en Magallanes el dia 25 de noviembre de 1851 ”. 
Importa destacar que, entre los seguidores de Cambiaso y, más todavía, entre los gestores de la idea del motín, destacan los soldados recientemente confinados, los ex sargentos del batallón Valdivia. Este había sido movilizado desde el sur a la zona central para amedrentar a los opositores y, en caso de asonada, contenerlos. El tránsito de la administración Manuel Bulnes al gobierno de Manuel Montt, líder conservador ampliamente resistido, supuso la más severa crisis político-militar interna desde los tiempos del ministro Diego Portales. En ese contexto, crispado por las suspicacias, en enero de 1851, se descubre una conjuración de los sargentos del Valdivia: entre los llamados a amilanar a la oposición, había prendido la activa desafección al régimen. Los responsables, tras un consejo de guerra, parten relegados a Punta Arenas; el 20 de abril el batallón se rebela en pleno; derrotado en las calles de Santiago, los sargentos sublevados (ahora destituidos) vuelven a engrosar la lista de los confinados; en vez de la pena de muerte originalmente dispuesta, se les condena a diez años de destierro en la remota colonia penal. Algunos de ellos (cuatro entre siete) morirán luego en el banquillo, junto a Cambiaso.

\section{LA SOCIEDAD DE LA IGUALDAD Y LOS GIRONDINOS CHILENOS}

Vicuña Mackenna había participado activamente en el proceso político conducente a la jornada del 20 de abril de $1851^{16}$. De modo que sus camaradas de armas en aquella iniciativa consagrada al avance de la causa liberal, acabaron convertidos en la "guardia pretoriana del sangriento dictador"17. La historia de Cambiaso, el monstruo, se cruza y se entrevera, entonces, con la biografía del autor: quienes asistieron al primero en el crimen, acompañaron al segundo en la lucha por convicciones que todavía, en plena década de 1870, sigue estimando valiosas y actuales. La intervención electoral no es, por desgracia, cosa del pasado: candidato opositor en la elección presidencial de 1876, Vicuña Mackenna acababa de experimentar una rampante intervención por parte del Ejecutivo.

El joven Vicuña Mackenna -integrante de la Sociedad de la Igualdad, ese fugaz laboratorio político de experiencias asociativas modernas y apelación directa al artesanado- desempeñó un papel protagónico en la agitación opositora contra el

16 Como introducción a la vida de Vicuña Mackenna, sigue siendo lectura obligada, aunque solo sea por los datos que aporta, la ya clásica biografía de Ricardo Donoso, Don Benjamín Vicuña Mackenna. Su vida, sus escritos y su tiempo. 1831-1886, Santiago, Imprenta Universitaria, 1925. El análisis crítico de su obra (más allá de la glosa temática superficial) y el esfuerzo por situar cruces mutuamente reveladores entre textos y biografía, tampoco han cundido entre otros estudiosos del personaje. Con todo, siguen resultando sumamente informativos los dos tomos de "Homenaje a Vicuña Mackenna" de los Anales de la Universidad de Chile (1931-32); y Eugenio Orrego Vicuña, Iconografía de Vicuña Mackenna, "primer volumen preliminar" de las Obras Completas de Vicuña Mackenna, Santiago, Dirección General de Prisiones, 1939. Para un estudio sugerente de Vicuña Mackenna con “constructor de nación”, véase José Luis Rénique, "Benjamín Vicuña Mackenna: exilio, historia y nación", en Carmen Mc Evoy y Ana María Stuven, eds., La república peregrina. Hombres de armas y letras en América del Sur, 1800-1884, Lima, Instituto de Estudios Peruanos e Instituto Francés de Estudios Andinos, 2007, 487-529.

17 Vicuña Mackenna, Cambiaso, 52. 
gobierno de Bulnes, exacerbada por la imposición de Montt como candidato oficial a la presidencia ${ }^{18}$. Con la intuición de acercarse a una encrucijada histórica, llevó un diario donde consta su audaz intervención en las maniobras conspirativas previas al conato de revolución ${ }^{19}$. Vicuña Mackenna escribió este diario para guardar un testimonio del transcurso de una experiencia que juzgó tocada por el aura de la historia. Hijo de un pipiolo víctima del destierro político, su lucha se identifica con la gesta idealizada de 1810. Para describirse a sí mismo y a los suyos, recurre a la categoría políticamente eminente de "patriotas"; luchando contra Montt, se siente reavivando la batalla irresuelta contra el "despotismo". Se trata, en suma, de un periodo de la vida de Vicuña Mackenna que él mismo recuperará, cada vez que se necesario, para validar sus credenciales liberales, enaltecidas a su vez por una filiación ilustre que remite a las luchas de la independencia.

En 1878, un año después de publicar Cambiaso, Vicuña Mackenna escribió la Historia de la jornada del 20 de abril: una batalla en las calles de Santiago, un libro que mezcla la crónica con las propias memorias del autor (recuerdos e impresiones cotejados con la lectura del diario personal recién aludido). La causa del autor -la misma que atribuye a la oficialidad del Valdivia- es la libertad electoral, ese afán por morigerar el poder de intervención del Ejecutivo, aduciendo el deseo de constituir un orden republicano con soberanía popular efectiva, sin elecciones fradulentas ${ }^{20}$. A décadas de distancia, puesto a rememorar, Vicuña Mackenna, narrador de una historia inicialmente clausurada por las prevenciones del secreto, ensalza el levantamiento del Valdivia como el "más osado y feliz levantamiento de que haya constancia en los anales militares de este país" 21 . Esta afirmación responde a una memoria mediatizada por la experiencia, y esta experiencia destila desilusión. En la Historia de la jornada, Vicuña Mackenna ajusta cuentas con su "ardiente adolescencia" embriagada con la "revolución" y, por tanto, también con sus compañeros de ruta.

Vista con la perspectiva de los años, la Sociedad de la Igualdad de Santiago le parece un remedo farsesco de las organizaciones políticas francesas. Las ideas radicales de sus líderes, Santiago Arcos y Francisco Bilbao, importadas "a fardo cerrado, de los clubes de París", le provocan unos comentarios irónicos e incluso un genio irritado, ausentes en las páginas de su diario de juventud. Toda la parafer-

18 Sobre la Sociedad de la Igualdad, véase Cristián Gazmuri, El “48” chileno: igualitarios, reformistas, radicales, masones y bomberos, Santiago, Editorial Universitaria, 1992.

19 "Diario de don Benjamín Vicuña Mackenna desde el 28 de octubre de 1850 hasta el 15 de abril de 1851", Revista Chilena de Historia y Geografía, tomo I, números 2, 3 y 4 (1911), 161-196, 449-474, 583-593.

20 Sin ir más lejos, uno de los sargentos del Valdivia publicó en La Barra, el periódico de la Sociedad de la Igualdad, una proclama en sintonía con las reclamaciones de la oposición liberal y las intenciones de Cruz como candidato no oficial: "Conocemos nuestro deber, decía el sargento escritor, y como soldados de la patria somos libres y no consentiremos jamás que la tiranía pretenda entronizarse y hacernos esclavos. Somos también pueblo y con el pueblo estamos mientras este defienda la libertad. Somos soldados de la patria, y como tales la defenderemos hasta el último instante". Cit. en Benjamín Vicuña Mackenna, Historia de la jornada del 20 de abril de 1851: una batalla en las calles de Santiago [1878], Santiago, Instituto de Historia Universidad Católica de Chile, 2003, 259-260.

21 Vicuña Mackenna, Historia de la jornada, 245. 
nalia de los clubes parisinos investidos con el prestigio de la Revolución Francesa, adquiere ahora un aire bufonesco, un dejo pueril e irrisorio, una desmesura sin otro propósito que replicar una historia ajena.

En vez de ajustarse al refractario contexto local (unos patricios pusilánimes, unos plebeyos políticamente inmaduros: una sociedad amansada por las prácticas autoritarias), esos misioneros se aplican a trasplantar a suelo estéril una cultura de la movilización política que brega en medio de la indiferencia o, peor, del interés que despiertan los espectáculos extravagantes: Bilbao, como un apóstol enviado de París, portando en procesión un árbol de la libertad o supervisando la erección de barricadas a la francesa, las mismas que en Europa surgen espontáneamente, como si la apacible Alameda de las Delicias, lugar de la pereza y los paseos galantes, pudiera albergar la energía levantisca de los boulevares. Los igualitarios de la capital hacen alardes, montan bravatas, meten bulla, remedan el radicalismo republicano en un juego coreográfico, en un baile de máscaras adoptadas del elenco revolucionario francés, pero en la hora crítica, cuando toca arriesgar la vida, se dispersan con la mansedumbre de las ovejas espantadas por el "pito de los serenos" 22 . Ilusionados por la narrativa maestra de la revolución de 1848 como actualización de 1789, carecen de una visión realista del escenario en donde se desenvuelven, y de los actores del reparto.

En su diario personal de ese tiempo, Vicuña Mackenna muestra confianza en el poder movilizador de Bilbao como tribuno y en la disposición del pueblo a plegarse a las acciones más confrontacionales de la oposición. Décadas después, se burla sin embargo de las quimeras de la Sociedad de la Igualdad, tanto como del temor despertado en la timorata sociedad de Santiago por ese "fantasma de sábanas blancas atadas en escobas y en árboles de mostacilla" 23 . Bajo la presión autoritaria, ese sujeto colectivo se esfuma; tras esa retirada sin gloria quedan algunos, pero como individuos aislados, residuos de un movimiento espectral y atomizado. Frustrados, esos eventuales mártires inútiles nunca conocerán (salvo Bilbao, que presenció la revolución de 1848 en París) la experiencia de comunión colectiva consagrada en las barricadas, el hito histórico en donde el espíritu de la revolución se pone a prueba.

Resulta interesante constatar las fuentes histórico-literarias de la fascinación por la Revolución Francesa por parte de la generación liberal nacida en torno a 1830. De esta manera, se puede ponderar mejor la densa significación política de la jornada del 20 de abril en la biografía de Vicuña Mackenna. Para esto, corresponde referirse a Los girondinos chilenos, texto redactado en octubre de 1876 para El Ferrocarril. En ese irónico artículo de reminiscencias, evoca las ínfulas revolucionarias de su generación.

En 1847, Alphonse de Lamartine había publicado la Historia de los girondinos, una extensa, arrebatadora historia de la Revolución Francesa que, narrada como una epopeya a la vez sublime y sangrienta, eleva sus personajes a alturas legenda- 
rias. Éxito editorial formidable, esta obra enardece a sus lectores y contribuye como pocas al culto de los revolucionarios, mártires de una religión sagrada. A Chile arriban los primeros ejemplares en febrero de 1848 y son comprados a precio de oro (más tarde el texto sería publicado por la prensa local en formato de folletín); en Santiago, los jóvenes liberales se congregan para leer el libro con una mezcla de recogimiento litúrgico, y una insólita exaltación de ánimo. Partícipe de ese fervor, Vicuña Mackenna nunca dejará de alabar a la Historia de los girondinos como el libro humano más sublime, como una "obra no del hombre sino de la divinidad" 24 . Aunque admita sus limitaciones (el rigor documental y expositivo subordinado a la licencia poética, a la euforia narrativa), siempre juzgará a ese texto como un potente evangelio político. A más de dos décadas de su lectura original, cuando Lamartine haya caído en el descrédito en Francia, y sus memorias recién editadas sean recibidas con un feroz encono crítico, persistirá en sostener a todo trance su grandeza póstuma, en virtud de sus dotes para transfigurar el "lodo en oro y la materia en vida" 25 . Para Vicuña Mackenna, esa cualidad alquímica logró una dimensión extraliteraria en la Historia de los girondinos. Consultó sus páginas como a un oráculo y a este le concedió el poder no solo de predecir sino también de inducir cursos de acción.

De hecho los jóvenes liberales lo leen, acá, en Chile, con la misma expectación con que aguardan las noticias procedentes de Europa. Los sucesos aparentemente detonados por la revolución de 1848 en París y la consiguiente "primavera de los pueblos" son interpretados bajo la modalidad de esa lectura profética. (Lamartine, el historiador inspirado de la Revolución Francesa, deviene orador sublime y ministro de la fugaz Segunda República inagurada tras el fin de la Monarquía de Julio). Volvamos a Vicuña Mackenna: “entre nosotros la repercusión de aquel entusiasmo revolucionario vibró en los corazones con mayor intensidad, porque la circulación del libro fue coetánea con las noticias de la revolución que su espíritu y su elocuencia habían engendrado. La luz llegó junto con el estampido, el soplo a la par con la creación. Los girondinos pasó, en consecuencia, a ser un libro de profecías como los Evangelios"26. En Francia se leía esa obra como el rescate de la memoria que acompaña el advenimiento de una promesa: un texto de historia leído como un escrito profético: "La Europa sintió a su lectura", cuenta la comtesse d' Agoult, "el estremecimiento peculiar que precede a los huracanes"27.

Esa promesa remite a la revolución truncada, abortada antes de su plena maduración. Así como los hijos e hijas de la Revolución Francesa añoraban retomar su

24 Benjamín Vicuña Mackenna, Una escursión a través de la inmortalidad o sea reminiscencias de los grandes hombres que en el curso de mi vida he conocido, en el Nuevo i en el Viejo Mundo, Santiago, Imprenta de "El Progreso", 1885, 50.

25 Benjamín Vicuña Mackenna, "Memorias inéditas de Lamartine", en Ricardo Donoso y Raúl Silva Castro, eds., Páginas olvidadas: Vicuña Mackenna en "El Mercurio", Santiago, Editorial Nascimento, 1931,43 .

26 Benjamín Vicuña Mackenna, Los girondinos chilenos. [1876], Santiago, Editorial Universitaria, 1989, 32. La edición citada cuenta con estudio preliminar de Cristián Gazmuri.

27 Esta cita, extraída de Los girondinos chilenos, 29, proviene a su vez de la Historia de la revolución de 1848 (1851) de Daniel Stern (seudónimo de Marie de Flavigny, comtesse d'Agoult). 
curso interrumpido por las herencias del Antiguo Régimen, los liberales chilenos, intelectuales desafectos con el régimen conservador, comenzaban a acostumbrarse a la idea del hito de la independencia como una ruptura parcial con el tiempo de la Colonia. En Chile y en Francia había unos proyectos vigentes, justamente porque no habían sido consumados.

La revolución francesa de 1848 causó una fuerte impresión en el resto de Europa, pero también en Latinoamérica. Su lenguaje democrático, su simbolismo republicano, su agenda igualitaria, sus prácticas de movilización y organización política de sectores sociales subordinados, se erigieron en gran referente ideológico y estratégico de los grupos disconformes con las inercias del orden tradicional, sea cual fuere su expresión particular. De México a Chile, pasando por Colombia, Perú o Uruguay, la "primavera de los pueblos" y, en especial, los sucesos de París, cuyos 'ecos' resultaban ahora más audibles, no tan desfasados, gracias a los avances de las comunicaciones, aportaron elementos catalizadores de la demanda antioligárquica por unas instituciones políticas auténticamente representativas y por una aplicación de la soberanía popular menos restrictiva, acorde con las disposiciones originales de las nuevas repúblicas ${ }^{28}$. La revolución francesa de 1848 sacude a los liberales chilenos, y esa conmoción abona su sentido de agencia política. "La que la había precedido en 1789, tan celebrada por la historia, había sido para nosotros, pobres colonos del Pacífico, solo un lampo de luz en las tinieblas. Su gemela de medio siglo más tarde tuvo al contrario", confiesa Vicuña Mackenna, "todas las afinidades de la luz y la irradiación. La habíamos visto venir, la estudiábamos, la comprendíamos, la admirábamos: nos asimilábamos a sus hombres por la enseñanza de ellos recibida, a sus acontecimientos por la prensa diaria, a sus aspiraciones por la república, que era la fraternidad a través de los mares y de las razas" 29 .

Como historiador y testigo de la agitación política que precede a la guerra civil de 1851, Vicuña Mackenna atribuirá a la revolución de 1848 la preeminencia de una causa primera: inicia un movimiento de los ánimos cuya fuerza de propagación ignora las fronteras, poniendo finalmente en sintonía al viejo y al "nuevo mundo". Este rapto de "afinidad", acota, "nos encaminaba fatalmente a la revolución universal" 30 . Por primera vez, en efecto, liberales como Vicuña Mackenna experimen-

28 Guy Thomson, ed., The European Revolutions of 1848 and the Americas, London, Institute of Latin American Studies, University of London, 2002.

29 Vicuña Mackenna, Los girondinos chilenos, 23.

30 Vicuña Mackenna, Historia de la jornada, 60. En 1853, residiendo en Londres tras su fuga de Chile, Vicuña Mackenna experimenta la comunión de los desterrados, de los náufragos del nacionalismo y de la experiencia democrática identificada con 1848 , en un meeting que, convocado para homenajear a la fallida revolución polaca de 1831, había reunido a todas las variantes del exilio político europeo. "Cada nacionalidad oprimida tenía ahí un apóstol, cada revolución fracasada contaba con un mártir en esa falange de proscriptos", dice. "Cuántos proscriptos nos habíamos ahí reunidos por la simpatía del dolor". Páginas de mi diario durante tres años de viaje. 1853-18541855, 2 tomos [1856], Santiago, Universidad de Chile, 1936, I, 389. En otras palabras, Vicuña Mackenna se siente o se describe como parte de una comunidad política internacional de intelectuales opuestos al orden establecido, dignificando su exilio de cara a los lectores chilenos. Sobre las relaciones entre exilio político y constitución de un "movimiento internacionalista entre los intelectuales", véase Christophe Charle, Los intelectuales en el siglo XIX. Precursores del pensamiento moderno, Madrid, Siglo XXI, 2000, 58-64. 
taban la sensación de sincronía histórico-política con Europa, y no, aún mejor, con sus continuidades e inercias, sino con las rupturas colectivas que aparentaban fundar un orden social promisorio; la revolución de 1789 la asimilan como algo distante en el pasado, sumergido en la penumbra, mediatizado hasta la indiferencia por la parsimonia de las lecturas; su actualización de 1848 la sienten como propia -casi chilena llegó a confesar el propio Vicuña Mackenna.

Según Bronislaw Baczko, en la época del activismo nostálgico de 1789 y su herencia inmediata, la "política aparecía como un inmenso teatro histórico donde se representaba el drama sublime de la libertad"31. Los asociados de Vicuña Mackenna interpretan ese drama de manera literal; tras leer a Lamartine, adoptan los nombres de los revolucionarios franceses del primer ensayo; Danton, Robespierre, Brissot, Marat o Saint-Just, son algunos de los "nombres de guerra" de los émulos chilenos, que así -envalentonados- se someten a un "bautizo revolucionario" 32 . No habría que considerar a ese gesto nominativo como un mero juego de identidades postizas. Esa teatralidad traduce la experiencia inédita en Chile de la Revolución Francesa como un patrón común, como un fenómeno universal en virtud, justamente, del alcance de sus principios, cualquiera fuera el anclaje espacial, cualquiera la fijación temporal de sus sucesos.

En definitiva, la Historia de los girondinos actuó como un estímulo para la acción y como una narrativa utilizada para infundirle sentido a las actividades conspirativas, aun frente a la eventualidad de la propia muerte. La noche del 20 de abril de 1851, en las horas previas al desenlace de la conspiración, Vicuña Mackenna recuerda haber ocupado su "primera velada revolucionaria en recorrer con intensa emoción las pájinas de los Jirondinos, que Lamartine consagra a la muerte de aquellos ilustres políticos" 33 . Esperando el momento acordado para integrarse al Valdivia, el aprendiz de revolucionario repasa episodios adonde no encuentra un guión de las acciones a seguir, sino la apoteosis romántica de unos héroes trágicos. En el diario que lleva en esos días intensos, Vicuña Mackenna aparece imbuido de una ética sacrificial, de una proclividad a la autoinmolación, a "conquistar vivo o muerto la gloria del que lucha por la libertad de la patria" (25 de diciembre de 1850). En definitiva, hay cierto bovarismo en la apropiación de Lamartine por los girondinos chilenos, toda vez que la lectura ofrece la satisfacción del deseo de una vida intensa y una conexión vicaria con los grandes dramas.

Vicuña Mackenna, según puede constatarse en pasajes autobiográficos de su vasta obra, experimentó la sensación de haber nacido a destiempo. Y en su caso, invariablemente, esa añoranza remite al periodo de la independencia. Por relaciones de familia, con unción casi religiosa, escucha desde su adolescencia relatos de los actores del proceso, narraciones de batallas y de los hechos de los grandes hombres que no alcanzó a conocer, con quienes nunca pudo intimar: O’Higgins,

31 Bronislaw Baczko, "El revolucionario", en François Furet, El hombre romántico, Madrid, Alianza Editorial, 1997, 280-81.

32 Vicuña Mackenna, Los girondinos chilenos, 55, 51.

33 Benjamín Vicuña Mackenna, Historia de los diez años de la administración de don Manuel Montt, Santiago, 5 vols., Santiago, Imprenta Chilena, 1862, I, 94. 
San Martín, los Carrera. "Los países son sus grandes hombres" es la cita de Lamartine que adoptó para caracterizar su propia forma de aproximación al pasado y al presente. De ahí su afición compensatoria por el género biográfico (de hecho narrará las vidas, no olvidemos, de O’ Higgins, de San Martín, de los Carrera).

De ahí también su costumbre, puesta en práctica en todos sus viajes, de visitar o de acercarse a las celebridades vivas, y de peregrinar a los sitios sacralizados por la memoria de los "grandes hombres" muertos. Hasta la "humilde alcoba" donde murió Bolívar, a orillas del Caribe, arriba Vicuña Mackenna, para "ponerse de rodillas" 34 . Durante su tercer viaje a Europa (1870-1871), admite que los cementerios son su "paseo favorito en todas las grandes ciudades" y, apenas puede, acude al campo de batalla de Waterloo, impaciente por experimentar en sí mismo las sensaciones provocadas por la "terrible planicie de los muertos", por ese "teatro de la gran carnicería”. Vicuña Mackenna es presa de una temprana pulsión sepulcral. Puede irrumpir en la escena de la agonía casi a la zaga del "obrero que viene a tomar la medida del féretro", o bien atisbar a distancia a las "altas personalidades", mientras integran un cortejo fúnebre, llegando a confesar su predilección por las eminencias muertas en desmedro de las vivas. Esta pasión necrofílica le lleva a buscar, donde quiera que se encuentre, las reliquias, las estatuas, las tumbas, las residencias, las calles que, por su vínculo cotidiano con los hombres inmortalizados por la gloria, hayan conservado remanentes de su aura. "Cuando los grandes espíritus que habitan la tierra emprenden su eterno vuelo, no lo llevan todo consigo. Algo queda en su nombre, en su morada, alrededor de su tumba".

Como historiador, como cronista, como viajero, Vicuña Mackenna quiere captar esa "huella luminosa". Leyendo la Historia de los girondinos se cruza con rastros de esa naturaleza radiante, y en su papel de revolucionario aspira a encarnar, más allá de la muerte, esa aura de grandeza ${ }^{35}$. Hace méritos para acceder al don de una vida póstuma.

\section{DISPUTAS POR EL CAPITAL SIMBÓLICO DEL LIBERALISMO}

En la Historia de la jornada, Vicuña Mackenna asume el lugar de enunciación del cronista, del historiador, del testigo y, más aún, del actor de época compelido a rememorar en virtud del mandato documental de la historia.

34 Vicuña Mackenna, Una escursión a través de la inmortalidad, 7.

35 Benjamín Vicuña Mackenna, "Una visita a la casa de M. Lamartine"; "Memorias inéditas de Lamartine"; y "Una visita al campo de batalla de Waterloo", todas crónicas de prensa reproducidas en Donoso y Silva Castro, eds., Páginas olvidadas, 23-29, 30-43, y 44-56, respectivamente. Para mayores señas de la temprana pulsión sepulcral de Vicuña Mackenna, léase el profuso relato de su primera experiencia como viajero (la travesía por América del Norte y Europa motivada por su exilio político de 1852 a 1855). Ahí desgrana visitas a cementerios y a tumbas de figuras históricas, que evidencian las inflexiones de una sensibilidad romántica afecta a los placeres de la melancolía ("romántico" es, de hecho, un adjetivo que asoma de manera espontánea en el contexto de esas experiencias). Para contrarrestar el vértigo de la metrópolis - la fatiga del mundano tráfago parisino- busca refugio en cementerios apartados. Y en la observación de funerales, a la vista del luto ajeno, descubre un paliativo a las tribulaciones del exilio y las nostalgias del viajero, llegando a manifestar que esas "escenas de dolor y de sensibilidad hacen siempre bien al corazón en la tierra extranjera”. Páginas de mi diario, I, 217. 
Como suele ocurrir con los textos directa o indirectamente autobiográficos, también la Historia de una jornada tiene la impronta de la autoimagen que Vicuña Mackenna poseía (o quería proyectar) hacia 1878 sobre su juventud como actor político. Esa imagen halagüeña -Vicuña Mackenna como el heredero de una revolución frustrada pero justa y todavía válida en lo relativo a sus principios- es el punto de partida del ejercicio de autorrepresentación, pues suministra la perspectiva a partir de la cual impone un orden al pasado. "Se recrea el pasado", dice Sylvia Molloy, "para satisfacer las exigencias del presente"36.

La jornada del 20 de abril representa una filiación identitaria. Para Vicuña Mackenna, el revolucionario, presto para la acción, debe tener memoria, todavía más si su bando ha sido derrotado. En 1858, comprometido de lleno en la oposición a Montt, empieza a trabajar en la Historia de los diez años de la administración de don Manuel Montt (1862); incluso mientras sufre su segundo período de prisión política (1858-59), no interrumpe la redacción de esta obra en cinco volúmenes: sintomáticamente, pasa sus días de encierro consagrado a narrar el sitio a las fuerzas revolucionarias de La Serena por parte de las tropas leales a Montt durante la guerra civil de 1851 .

Contrariamente a lo indicado por el título, en las páginas de la Historia de los diez años, solo relata, aunque pormenorizadamente, los avatares de la guerra civil de 1851 , esos días en que se podía aprender a vivir "en una especie de domesticidad con las balas i con la muerte" 37 . Y confiesa: "Soi [...] el soldado de una causa jenerosa i desdichada. Simpatizo con ella desde el fondo de mi corazón, como la deidad de mi juventud i de mis sacrificios, i la guardo además como una sagrada herencia de mis mayores". Ya en esta obra "nacida en las borrascas" anunciará la futura redacción de la Historia de la jornada -primer eslabón de la cadena revolucionaria, aunque última etapa en el orden de la escritura- como parte integral de este gran fresco político-militar. Ambos libros suponen un proyecto común ${ }^{38}$.

La Historia de los diez años constituye el esfuerzo inicial por resarcirse de la derrota en el campo de batalla y mantener viva una causa, sosteniendo una comunidad política mediante la elaboración de una memoria colectiva. Es sintomático que Vicuña Mackenna se haya aplicado al trabajo de recolección de información ya en 1852. Convoca a sus camaradas de ayer bajo el imperativo de proveerle materiales para la composición de un texto que haga justicia a sus empeños frustrados, poniendo de manifiesto sus sacrificios y la nobleza de sus esfuerzos. Habla de un culto a la libertad, y este tiene sus mártires oscuros y sus héroes sin fanfarria y sus ciudadanos incorruptibles; el libro es el homenaje a la "causa de los vencidos escrita durante el reino de los vencedores" 39 . Al rescate de esta memoria revolucionaria -grande hasta en sus extravíos, como murmura el estribillo de fondo aún perceptible en la Historia de la jornada- Vicuña Mackenna le asigna un valor

36 Sylvia Molloy, Acto de presencia. La escritura autobiográfica en Hispanoamérica, México, COLMEX-FCE, 1996, 199.

37 Vicuña Mackenna, Historia de los diez años, II, 127.

38 Ibid, I, 7-8.

$39 \quad$ Ibid., I, 19. 
cívico presente: resaltar esos "altos ejemplos de entusiasmo i de consagración cívica" que, desacreditados por la "calumnia", reclaman de parte de la historia contemporánea su rehabilitación en el "corazón del pueblo" y, a la par, imponen el desahucio de los "malvados, que en política no son para nosotros sino los traidores i los apóstatas" 40 .

Nada peor que los traidores y apóstatas del liberalismo; nada peor, postula Vicuña Mackenna, que los liberales que habiendo luchado por la libertad electoral, tras alcanzar el poder, remedan los vicios del Antiguo Régimen, usurpando el derecho a sufragio. Esa reparo de 1862 (un temor ya presente en los igualitarios de 1850, tal como apuntó Vicuña Mackenna en su diario, el día 3 de noviembre) se hizo realidad, y de modo contundente, a mediados de la década de 1870. La intervención electoral del presidente Federico Errázuriz Zañartu en perjuicio suyo y a favor del candidato oficial Aníbal Pinto, es fundamental para comprender las afinidades, hasta ahora ignoradas, entre textos en apariencia tan disímiles como Los girondinos chilenos y la Historia de la jornada, por un lado, y las historias de Cambiaso y la Quintrala, por otro.

Directa o indirectamente, tanto en Los girondinos chilenos como en la Historia de la jornada, Vicuña Mackenna desliza comentarios mordaces sobre Errázuriz, a quien retrata como un renegado del liberalismo, poseído por una desmedida ambición de poder, superando incluso a los maestros de la vieja escuela conservadora en el arte de las prácticas electorales fraudulentas y la consiguiente adulteración del principio de la soberanía popular. Vicuña Mackenna, ex intendente de Santiago (1872-75) durante su administración, resiente la actitud del presidente, quien le aseguró en privado su voluntad de prescindencia con miras a las elecciones de 1876, para luego tomar partido por Pinto, aplicando al éxito de su candidatura la contundente maquinaria oficialista.

Esa campaña presidencial había marcado un hito en la historia de las prácticas políticas: por primera vez, alentado por las democratizadoras reformas electorales de 1874, un candidato recorre el país en tren, implementando un vibrante trabajo de campaña, más inclusivo, más abierto al trato directo con la ciudadanía, en la esperanza de poder retar seriamente al Ejecutivo ${ }^{41}$. Con su descentralizadora "campaña de los pueblos", animada por meetings y banquetes bien abastecidos de oratoria popular, Vicuña Mackenna se convirtió en un potente precursor de la cultura de la movilización política ${ }^{42}$.

$40 \quad$ Ibid., I, 17.

41 Rafael Sagredo Baeza, Vapor al norte, tren al sur. El viaje presidencial como práctica política en Chile. Siglo XIX. Centro de Investigaciones Diego Barros Arana-El Colegio de México, Santiago, México D.F., 2001, 98-115. El liberal Isidoro Errázuriz, gran promotor de las "leyes laicas", fue uno de los oradores que acompañaron en su gira a Vicuña Mackenna. Como el historiador, también resintió el vuelco autoritario de su viejo correligionario, llegando a afirmar, en el prólogo de su Historia de la administración Errázuriz (1877), que los "indecentes manejos electorales" del pasado "han vuelto a adquirir en nuestros días la importancia de instituciones gubernativas".

42 Sobre la función de los oradores en tanto articuladores de esa cultura de la movilización, véase Manuel Vicuña, Hombres de palabras. Oradores, tribunos y predicadores, Santiago, Editorial Sudamericana, 2003. 
Las biografías de los monstruos son alegorías políticas en parte ligadas a esa coyuntura decisiva en la vida pública de Vicuña Mackenna; indirectamente, participan del esfuerzo por constituir y apropiarse de una memoria revolucionaria llamada a investir de autoridad a sus legítimos legatarios. Ya se verá que con Cambiaso buscó sanear su vínculo con el momento inaugural de su carrera política, toda vez que la importancia de esa filiación identitaria había cobrado fuerza tras su campaña presidencial; como único candidato de oposición, Vicuña Mackenna había aceptado el apoyo del Partido Conservador, matrimonio de conveniencia voceado como una claudicación oportunista por parte de los sectores afectos al gobierno de la Alianza Liberal. Revalorizar su pasado -al tiempo que dictamina expiradas las antiguas credenciales liberales de Errázuriz, aduciendo su presente autoritarismo- es una forma de recuperar una identidad escamoteada.

Que las derivaciones de la "campaña de los pueblos" constituyan un órgano textual más o menos oculto en libros sobre temas tan alejados de su órbita inmediata de referencia, señala la trascendencia de esa experiencia para el autor. En algo más que en la monstruosidad, la Quintrala y Cambiaso están unidos; sus historias comparten una misma función política. Los Lisperguer y la Quintrala admite varias lecturas, y varias han sido ensayadas ${ }^{43}$, si bien existe una hasta ahora desatendida: la historia de la Quintrala y de su familia como el relato aleccionador sobre las negativas implicancias de la política del parentesco. En términos genéricos, los Lisperguer son descritos no solo como la familia más importante del siglo XVII y como el tronco del cual proviene la entreverada ramificación endogámica de la 'aristocracia' chilena, sino además como el grupo parental que fundó una práctica política consistente en usar sus vínculaciones familiares, estratégicamente situadas en los distintos ámbitos del poder, como una red de apoyo susceptible de vulnerar y desconocer, flagrantemente, el imperio de la ley.

La Quintrala, la potentada sádica, ejemplifica eso como nadie: pese a la magnitud de los crímenes de esa "tigre hembra", ávida de sangre y transgresora de todos los tabúes, nunca pudo ser condenada por la justicia. Esa organización parental no es algo exclusivo del mundo colonial; Vicuña Mackenna dice que continúa activa en la república (no obstante sus ínfulas modernizadoras respecto a ese pasado):

"Tócanos ahora seguir el hilo de la descendencia de unos y otros, o con paciente prolijidad desenmarañar su trama y su tejido en el espacio de dos siglos, pues con los años los Lisperguer hicieron de todo Santiago social y doméstico una indescifrable

43 Sobre la Quintrala y sus resemantizaciones literarias, véase, por ejemplo, Lucía Guerra, “Maldita yo entre las mujeres de Mercedes Valdivieso: resemantización de la Quintrala, figura del mal y del exceso para la 'chilenidad' apolínea”, Revista Chilena de Literatura, No 53 (1998), 47-65; Rosa Sarabia, "Doña Catalina de los Ríos y Lisperguer y la construcción del monstruo Quintrala", Anales de Literatura Chilena, $\mathrm{N}^{\circ} 1$ (2000), 35-52; Natalia Cisternas Jara, "La Quintrala como construcción discursiva. Análisis al diseño historiográfico de Catalina de los Ríos Lisperguer de Benjamín Vicuña Mackenna", Anuario de Postgrado, Universidad de Chile, No 4 (2001), 429-38; y María Eugenia Albornoz Vásquez, "Develando una simbólica subterránea: Catalina cruzada por Mercedes en Maldita yo entre las mujeres", Cyber Humanitatis, $\mathrm{N}^{\mathrm{o}} 23$ (invierno 2002). 
madeja. Tarea es esta que no tiene por base ciertamente un necio interés genealógico, sino el estudio íntimo de una sociedad que fue toda una familia, y en gran manera lo es todavía, lo cual alumbra, porque hasta hoy día casi todo pasa entre nosotros, entre tíos y sobrinos, entre primos y cuñados... Ejemplo vivo de esto fue tal vez aquella famosa Asamblea de Notables, llamada así porque lo fue de parientes, congregación, por tanto, genuinamente santiaguina, que hace un año de esta fecha resucitó viva la difunta Colonia en nuestro suelo. Porque en fin de cuentas fueron los Lisperguer de Santiago y sus yanaconas de todo el territorio los que decretaron nuestro último cambio de gobierno. Y así ha de verse si conviene o no a la República el que alguien emprenda [...] estas exploraciones por los capítulos, intrigas y sepulturas del pasado" 44 .

¿La famosa Asamblea de Notables? Los primeros lectores de este texto, presumiblemente inmersos en una narración sobre tiempos remotos, son súbitamente atraídos, mediante el impulso de esa alusión, al ruedo de la actualidad política.

En 1875 se había constituido una Asamblea de Notables a instancias del gobierno, con el propósito de acordar la candidatura oficial de Pinto a partir de un ritual engañosamente deliberativo incensado con fraseología republicana. Sin hacer acusaciones al bulto, individualizando a sus blancos, Vicuña Mackenna se apresuró a denunciar el asunto como una farsa, como un "sainete político", como una "tramoya de las alturas", publicando un panfleto "dedicado a los republicanos de Chile", cuyo autor prefirió identificarse como un "liberal de nota" 45 . Quienes integraron esa multitudinaria asamblea nos han "hecho retrogradar sesenta i cinco años en el camino de un visible progreso democrático", a tiempos previos a la independencia, ungiendo con docilidad cortesana al candidato del "amaño" del presidente, así complacido en su "plan dinástico de sucesión personal". Forman la asamblea familiares de Errázuriz, de Pinto (ministro de Guerra del primero) y de los "leales" del "rey" (desde ministros a intendentes). La lógica parental oligárquica converge y se cruza con las presiones de la "máquina administrativa", que fuerza el acatamiento o la complacencia en funcionarios públicos de todo nivel, imponiendo la "voluntad de una gran señor" por sobre la voluntad del "pueblo chileno".

Es decisivo que Vicuña Mackenna asuma el lugar de enunciación del liberal airado por la impostura de ese artificio proclamado, para peor, como "obra del 'partido liberal'". Si algo resiente el candidato opositor (pues, en el fondo, en esa calidad escribe), eso es que se "afirme que los 'liberales que no hayan encorbado la frente delante de esas horcas caudinas de la dignidad humana no son liberales sino traidores, es decir, "clericales"”. Escribiendo sobre los girondinos chilenos, Cambiaso, la Quintrala o la jornada del 20 de abril, Vicuña Mackenna se compromete, desde diversos frentes textuales, en la querella por la identidad liberal, por lo visto un valioso bien simbólico reclamado indistintamente por quienes detentan el poder

44 Benjamín Vicuña Mackenna, Los Lisperguer y la Quintrala. Doña Catalina de los Ríos [1877], Santiago, Editorial Sudamericana, 2001, 149.

${ }_{45}$ La asamblea de notables, por un liberal de nota, dedicado a los republicanos de Chile. Imprenta de "El Independiente", Santiago, 1875 
(la Alianza Liberal) con avidez compromitente de sus antiguas banderas de lucha (la libertad electoral); y, por otra parte, los "liberales desheredados, los liberales excluidos, los liberales traidores porque somos fieles hasta el sacrificio a nuestras más santas i más queridas tradiciones" 46 .

Esas "queridas tradiciones" autorizaban una identidad liberal definida no a partir de las disputas ideológicas en curso con la Iglesia Católica y el Partido Conservador (la estrategia de la Alianza Liberal), sino en función de la lucha por la libertad electoral y el ejercicio no fraudulento, a todo trance, de la soberanía popular (la estrategia de los liberales marginados del gobierno y acusados de apóstatas, como el propio Vicuña Mackenna).

\section{LA ESCRITURA HISTÓRICA COMO PROFILAXIS POLÍTICA}

La participación de los ex sargentos del Valdivia en el motín de Magallanes, un alzamiento que siempre ostentó su adhesión al bando del general Cruz, aportó argumentos persuasivos a favor de quienes, afectos al orden conservador, buscaban desbancar su autoridad frente a la ciudadanía desafecta. El 11 de enero de 1851, el mismo día en que el comandante general de Marina fue informado, gracias a un vapor arribado a Valparaíso, de los sucesos de la remota colonia, redactó una comunicación urgente dirigida al ministro de Guerra y Marina, en la cual alertaba sobre los "horribles crímenes perpetrados al grito de jviva Cruz! con el objeto de unirse a sus partidarios, que consideran triunfantes en la República" 47 . A esa altura, Cruz ya había sido derrotado en la batalla de Loncomilla (8 de diciembre de 1851), dándose por concluida la guerra civil; las noticias del presunto desembarco de las fuerzas amotinadas amenazaba, ahora, con perturbar la paz de plomo recién ganada.

La asociación entre Cambiaso y Cruz irrita a Vicuña Mackenna; lo alcanza a décadas de distancia, y aún lo punza. Después del horror inicial, del estupor del primer momento, tal como recordaba en 1877, "vino el soplo emponzoñado de los partidos políticos a acrecentar la llama de la cólera oficial. Llegó a decirse que los asesinos de Magallanes eran los naturales aliados políticos de los nobles soldados que habían sucumbido venciendo en el sangriento campo de Loncomilla hacía apenas unos pocos días, i esto recrudeció -si ello era posible todavía- el encono ardiente en que la familia chilena vivía sombría i descontenta, dividida en dos campos de odio". Ese encono, condimentado con la sangre de las víctimas de Cambiaso, sirve para degradar y azuzar las represalias contra el "noble i glorioso partido que había caído con su bandera en el campo de batalla, pero sin

46 Años después, Vicuña Mackenna, crítico persistente de la administración Pinto, volvería a atacar la farsa republicana, "aquel famoso escamoteo" tramado en La Moneda con "toda la audacia y desenfado, que en aquel tiempo, por vía de ensayo, se gastaba en la usurpación del derecho conferido al pueblo por las leyes y la constitución". Véanse sus "Reminiscencias de una Convención o sea la Asamblea de Notables de 1875 (1875-1881)", El Mercurio, Valparaíso, 10 de enero de 1881.

47 Cit. en Vicuña Mackenna, Cambiaso, 208. 
tender en parte alguna su mano ni a los asesinos, ni a los incendiarios, ni a los piratas" 48 .

A la hora del crimen, Cambiaso invoca a la política del liberalismo como validación ideológica de sus acciones y, en efecto, la prensa afín al gobierno explota esa asociación, atribuyéndole a su régimen criminal la función corrosiva de revelar la verdadera naturaleza de la revolución y el futuro de atrocidades que le esperaba al país en caso de haber triunfado. Todos los episodios previos de la guerra civil habían permitido adquirir conciencia "sobre el carácter aproximativo de la revolución i de sus actores, pero no sobre el carácter verdadero de una i otros"49. Cambiaso aparecía entonces como la clave de acceso al secreto de la revolución y a la idiosincrasia de los revolucionarios: de Vicuña Mackenna; de sus hermanos implicados activamente en el conflicto, tanto en el frente sur como en el norte; y de su padre, gran impulsor de la guerra civil de 1851 y, ya en eso, hombre de confianza del propio Cruz en el teatro de campaña. Ese vínculo odioso, reactivado por el motín magallánico de 1877, abruma al historiador. La escritura de Cambiaso responde al esfuerzo por librarse de ese contagio.

Vicuña Mackenna oscila entre dos polos al momento de caracterizar al monstruo. Por una parte, lo bestializa con el ánimo de expulsarlo del género humano, hasta una distancia de alcances profilácticos; hiena de cementerio, buitre insaciable, tigre ávido de la sangre de sus víctimas: así le llama para degradarlo. Por otra parte, Cambiaso aparece como un hombre cuya monstruosidad reside en la racionalidad criminal que rige sus actos; no es víctima de las pasiones, no es títere de los instintos, no sufre el arrebato de la locura; todo lo que hace se ajusta a una lógica tan glacial como asesina. Es un hombre con buena formación para los rudimentarios estándares de la época (alfabetizado, apasionado por las ciencias naturales, dotado de capacidad analítica) y, por eso, un disolvente del optimismo ilustrado. Cambiaso, el "monstruo caviloso", presta atención a los detalles y luce el espíritu previsor asociado a la inteligencia cultivada. Su violencia aspira a la regulación reglamentaria. Esquiva el desborde eruptivo.

Por algo crea un código de sanciones denominado Crímenes militares y penas que a ellos corresponden. Penalizando acciones puntuales, regimenta el terror e

48 Vicuña Mackenna, Cambiaso, 209. Vicuña Mackenna escribe Cambiaso sin tener a la vista la causa criminal, que inicialmente cree extraviada; para suplir esa carencia, se apoya en la prensa de la época, nacional y aun extranjera, y, sobre todo, en documentos inéditos que fue copiando o recopilando durante años. Ahora bien, aunque no tiene a la vista la causa criminal, igualmente su relato concuerda con la información contenida en esos legajos, parte de los cuales habían reproducido los diarios de la época. La causa no solo contiene las declaraciones de testigos e inculpados; también incorpora los documentos del régimen de Cambiaso que, en esto, conservó las formas de la burocracia militar. En uno de esos textos (19 de diciembre de 1851), alusivo a las deliberaciones y a los acuerdos sobre los pasos a seguir por los insurgentes, puede leerse: "nos es mui favorable el dirijirnos a Arauco, pues en este no tenemos el menor tropiezo, ni tenemos quien se nos oponga por ser toda esa jente de fuerte del Candidato popular, Don José María de la Cruz i con el grito de ¡viva Cruz! será suficiente para que se nos reunan todos los que con ansias esperan esta oportunidad de engrosar las filas del Ejército Libertador i que, si no lo han hecho, es conocido que sus Jefes vendidos al oro del tirano se lo han impedido con las amenazas y prisiones, i una vez ahí, marcharemos adonde el honor nos llame". Firma Enrique Salas, secretario. ANCh, Fondos Varios 116, 40b.

49 "La Civilización", La Civilización, Santiago, 5 de abril de 1852. 
introduce un orden del suplicio y la tortura. En lugar de la aleatoriedad de un poder fuera de sí, desbocado, favorece un régimen basado en el rigor de unas reglas homicidas, exacerbación frenética, en parte, de las disposiciones más extremas de las Ordenanzas de Su Majestad para el régimen, disciplina, subordinación y servicio de sus ejércitos, aún vigentes en Chile en esa época ${ }^{50}$. Tal como propone Vicuña Mackenna, en Cambiaso se funde la sangre y la tinta: el crimen es formalizado mediante disposiciones escritas, es sometido a método para honrar el celo administrativo de una inclemencia moralizante. Cambiaso hace más que disponer fusilamientos, harto más que decretar ahorcamientos; dependiendo de la falta, ordena arrancar lenguas, quemar cadáveres u "ojos con un fierro caliente hasta carbonizarlos"; manda descuartizar a infractores vivos, "presa por presa, principiando por los dedos de las manos, prefiriendo la derecha" 51 . Cambiaso legisla con un ánimo punitivo arcaizante, que a la vez sistematiza, docifica y alimenta la violencia. Dracón implacable, su código constituye, por su asfixiante severidad, un programa virtual de exterminio de su propio ejército.

$\mathrm{Su}$ imagen como habitante de un bestiario sanguinario (una convención literaria) queda supeditada a la otra, la verdaderamente inquietante: Cambiaso como monstruo reflexivo. Esta inteligencia luciferina explica su capacidad persuasiva. Diabólico, domina las artes del fingimiento. Manejaba la "palabra como el puñal, recto al corazón”, dice Vicuña Mackenna ${ }^{52}$. Arrastra a los demás en dirección al mal, camino a la degradación, aunque haciéndoles creer, durante la mayor parte del trayecto, que así servían a una causa noble, la de la libertad. Bajo el amparo de esa postiza legimitidad política, trama sus crímenes; simula el arrojo del ethos revolucionario, si bien su único interés es pecuniario (fugarse con el botín). Hasta su bestialización participa a veces de esta idea. Cambiaso es la serpiente que hipnotiza a sus víctimas, sustrayéndoles su autonomía; posee, “como ciertos animales dañinos, condiciones raras para el mal i el engaño: era ventrílocuo, i parecíase al cocodrilo en que podía hincar su puñal en su presa finjiendo el llanto de un niño"53.

Esta caracterización cumple un servicio importante. Bajo esta premisa, quienes secundan al monstruo son víctimas de un hechizo; y Cambiaso, el libro, no hace más que narrar la historia de una alienación transitoria. Esta le habría costado la vida aunque no la dignidad a sus víctimas. Como es costumbre, Vicuña Mackenna piensa ante todo en los ex sargentos del Valdivia, desentendiéndose del resto de los implicados. Tras un tiempo de duda, en que aceptan huir, cobardemente, asustados por la magnitud de sus crímenes y la perspectiva de su castigo, esos "hombres de bronce" (los "mismos de la revolución de abril", no tarda en precisar), recuperan el temple perdido y asumen virilmente su extravío. Son condenados a muerte, pero ante esa prueba decisiva, se comportan como héroes, estoicamente. Se trata, en propiedad, de una tragedia: de la ruina de unos héroes malogrados, enceguecidos por la hýbris de la audacia política.

\footnotetext{
50 Braun Menéndez, Cambiazo, 106.

51 Cit. en Vicuña Mackenna, Cambiaso, 174, 176.

52 Vicuña Mackenna, Cambiaso, 218.

53 Ibid., 64.
} 
Aunque Vicuña Mackenna llame a Cambiaso un "abominable sátrapa” e invoque la idea del monstruo moral como fábula política de los extravíos paroxísticos del poder despótico, el fugaz tirano de Magallanes distó de ejercer un mando absoluto. Para empezar: son los ex sargentos del Valdivia quienes le invitan a convertirse en caudillo de la revuelta. Cambiaso ni siquiera interviene en deliberaciones tan relevantes como el simulacro de juicio que le costó la vida al gobernador. Y en la colonia alzada, tal como consta en el libro del propio Vicuña Mackenna, hay espacio para el cabildeo, la discrepancia y el contrapeso del sufragio disidente. Para actuar, el "sátrapa" a veces requiere de consensos o de mayorías; no hace o deshace a voluntad; inclusive somete a votación decisiones arriesgadas, compromitentes, descartando un curso de acción controvertible (nuevos asesinatos) cuando este no cuenta con el apoyo unánime de sus "consejos de guerra".

En el juicio criminal contra los alzados, Cambiaso se resistirá a interpretar el papel de chivo expiatorio, señalando que los ex sargentos inculpados alegaban una falsa inocencia. En el cadalso, ante la multitud, insistirá en ello: que los hombres destinados a morir a su lado, aun cuando alegaran lo contrario por oportunismo, habían sido sus auxiliares. Exculparse aduciendo el miedo pánico a su figura macabra era una manera larvada de apelar a la monstruosidad de un líder incontrarrestable en su poder de perdición colectiva. Como defensa de los hombres del Valdivia, esa resultó una estrategia fallida: igual murieron a su lado, con la túnica blanca del ajusticiado.

Fallida o no, Vicuña Mackenna la retoma y la radicaliza. En último término, uno puede pensar que de eso se trata Cambiaso. Del intento por concentrar todo el mal en una persona, a fin de purificar la causa política del liberalismo, de la cual Vicuña Mackenna se considera legítimo heredero. Cambiaso es el nombre de un individuo y la marca de un contagio. Es un agente de polución. En su día contaminó a Cruz, a quien Vicuña Mackenna se urge en preservar "inmaculado"; a sus seguidores, entre los cuales se cuenta el historiador, sus hermanos y su padre, secretario personal del general alzado; y a eso que les llevó a tomar las armas, la libertad electoral, un derecho cuya carencia se la ha vuelto tan agraviante como en el pasado.

Bajo esta luz cobra relieve otra función del texto: actuar sobre la memoria como una purga, o mejor, como la operación quirúrgica de remoción de un tumor. Vicuña Mackenna aspira a retirar del cuerpo de la revolución liberal, no un tumor nacido como emanación patológica de esa causa ilustre, sino como parásito disimulado. De ahí que lea todos los actos de Cambiaso bajo la lógica de la sospecha: sus saludos a la bandera de la revolución, no son más que alardes interesados, tácticas de seducción, una "pantomima de guerra" destinada a "lisonjear el sentimiento belicoso de los ex sarjentos de abril" ${ }^{54}$. Como ministro del tribunal de la historia, "rejenta del mundo moral", Vicuña Mackenna evoca (o convoca, alegando imparcialidad) al "propio reo, a quien imponemos el terrible castigo que estas pájinas estampan" 55 . ¿En qué consiste ese castigo? En absorber la totalidad de la

54 Ibid., 182.

55 Ibid., 268, 237. La idea de Cambiaso como el "monstruo de Magallanes" le venía de antiguo; así le designa en la Historia de los diez años, II, 217; en 1877, elabora esa designación originaria. 
culpa a perpetuidad. Los ex sargentos, por efecto del contraste aleccionador, quedan en condición de ser absueltos en la memoria decantada de los hechos.

Cambiaso busca rehabilitar a los ex sargentos caídos, reintegrarlos a la condición humana y, como resultado de esta operación, apuntalar los límites entre la barbarie y la civilización, esa antítesis fundamental en la historia hispanoamericana del siglo XIX. Como libro, en efecto, Cambiaso integra, aunque desde una posición periférica (periférica en pertinencia y también en calidad), la literatura de frontera ejemplificada por el Matadero de Esteban Echeverría o el Facundo de Domingo Faustino Sarmiento. Vicuña Mackenna conoce el Facundo y en las Tablas de sangre de José Rivera Indarte, descomedido fustigador de Rosas, aprendió a frasear las diatribas contra el régimen del terror de la Mazorca. Él mismo alude a esa filiación literaria de los desterrados argentinos cuando alega que Cambiaso representa la "emanación" y el "espectro" de Rosas en los confines del "desierto" 56 . En la jerarquía del crimen, el aislamiento profiláctico de Cambiaso es reforzado por la vía de la excepcionalidad. Como "encarnación absoluta del mal”, nadie está a la altura de su naturaleza asesina ${ }^{57}$. Nadie, salvo Rosas.

Relatando la primera toma de posesión fallida del Estrecho de Magallanes en el siglo XIX, Vicuña Mackenna define a sus actores como "aquellos rudos conquistadores del desierto", y a las dos únicas mujeres de esa expedición pionera, como las "matronas esforzadas que mecieron las primeras cunas de una nueva patria al silbido de los huracanes" 58 . Ese espacio inhóspito, inclemente, en donde la imprevisión conduce a la tragedia y la hambruna aprovecha el menor descuido para cobrarse nuevas víctimas, representa una frontera a la vez territorial y cultural. Se trata de un lugar a trasmano, remoto, perdido en los márgenes del territorio nacional, reacio a la imposición de la soberanía del Estado; representa asimismo un territorio situado fuera del orbe civilizado. De este modo, la colonia deviene en enclave comisionado para asentar ambas soberanías. Considérese que la primera iniciativa de colonización ya contó, según la Memoria de la Guerra de 1844, con un "celoso capellán que se empleará en ganar para la fe i la civilización las tribus salvajes de las cercanías" 59 . En suma, el Estado nacional delega en sus enviados la misión de propagar la civilización de la cual se juzga legítimo exponente.

Vicuña Mackenna acentúa, en el escenario magallánico, el "carácter transitivo" de las fronteras ${ }^{60}$. En la orilla sur del Estrecho localiza (o imagina más bien) una "tribu entera de horribles caníbales" 61 . Y no solo eso: la sombra de la antropofagia como epítome de la barbarie además se radica en el corazón del enclave civilizado. Cuando narre la fuga (a la larga fallida) del gobernador, Vicuña Mackenna aludirá a la noche triste: el gobernador cautivo es igualado a Cortés en su huida de Tenochtitlán y, por

56 Vicuña Mackenna, Cambiaso, 269.

57 Ibid., 266

58 Ibid., 7-8

59 Cit. en Vicuña Mackenna, Cambiaso, 12.

60 Vanni Blengino, La zanja de la Patagonia. Los nuevos conquistadores: militares, científicos, sacerdotes y escritores, Buenos Aires, FCE, 2005, 170.

61 Vicuña Mackenna, Cambiaso, 111. 
inferencia, los sublevados son parangonados con los aztecas. Magallanes constituye una frontera múltiple, un umbral territorial y cultural hacia el dominio a la vez externo e interno de la barbarie. Por eso en aquellos "remotos destinos", acota el autor, el "hombre es de mayor peligro que el mar embravecido"62.

La monstruosidad de Cambiaso constituye una suerte de 'cordón sanitario' 1lamado a apartar la esfera de la civilización del ámbito de la barbarie. Lo monstruoso de Cambiaso no pasa tanto por sus crímenes. Lo verdaderamente monstruoso es su exposición ejemplar de la precariedad de la identidad humana, de la vulnerabilidad de todos quienes, no obstante haber sido relegados a Magallanes en virtud de una causa valorada como altruista, súbitamente degeneran en hombres bestializados.

Cambiaso sugiere el esfuerzo por externalizar algo que reside en el interior de cada cual, algo capaz de hacerse soberano una vez que los lazos de la civilización se aflojan. Cambiaso como monstruo -o el horror que provoca su historia- responde a la constatación de la fragilidad de la identidad civilizada. El afán por poner en cuarentena la monstruosidad, confinándola al interior de Cambiaso, revela el temor a la inminencia de un contagio. El extravío de sus antiguos compañeros de armas perturba al historiador liberal porque muestra que el monstruo no es por fuerza el otro, la alteridad radical, el extranjero inasimilable, el inhumano; al contrario, reside en uno como una latencia, como un inquilino subrepticio, y este puede despertarse de golpe, usurpando el control del propio yo. La alteridad radical del monstruo no es discontinua con el yo civilizado, la condición humana o las causas políticas enaltecidas por un ethos liberal. Las figuras de la otredad como Cambiaso discriminan, mediante el gesto del repudio, lo propio de lo ajeno; disponen una frontera de resguardo simbólico; ficticiamente, expulsan de la propia identidad, traspasándolo a unos seres de drástica extrañeza, lo que más nos atemoriza en nosotros ${ }^{63}$.

Entre los crímenes del régimen de Cambiaso, el asesinato de los tres extranjeros (los capitanes de los dos barcos capturados, más uno de sus tripulantes) tiene una significación especial. Para Vicuña Mackenna, esos hombres representan a "otra

62 Ibid., 11. El problema de las fronteras con la "barbarie" cruza la vida y la obra de Vicuña Mackenna. Como parlamentario, en agosto de 1868, se ocupa de la cuestión de Arauco en la Cámara de Diputados. Ahí alienta la conquista militar de la Frontera, conceptualizada como un combate sin mediación posible entre la civilización y la barbarie. Benjamín Vicuña Mackenna, La conquista de Arauco. Discurso pronunciado en la Cámara de Diputados en su sesión de 10 de agosto, Santiago, Imprenta del Ferrocarril, 1868. Años después, cuando sea intendente de Santiago, se afanará en trazar un "camino de cintura", esto es, una avenida de circunvalación destinada a cumplir la función de un "cordón sanitario". En su interior, quedaría bajo resguardo físico y moral, el "Santiago propio, la ciudad ilustrada, opulenta, cristiana"; en su exterior, la "ciudad bárbara", el aduar africano, la población arrabalera, la zona de la indigencia en todo orden de cosas. Benjamín Vicuña Mackenna, $L a$ transformación de Santiago, Santiago, Imprenta de la librería del Mercurio de Orestes L. Tornero, 1872, 18-19, 24-25. Al margen de su función racionalizadora e higiénica (aislar las áreas donde brotaban las emergencias sanitarias), el "camino de cintura" simbolizaba la antinomia identidad/alteridad, a la vez que acentuaba las diferencias socioculturales a través de una organización urbana compartimentada. Marcaba una frontera entre el centro como identidad (la ciudad propia, ilustrada, cristiana) y la periferia como alteridad (la ciudad bárbara, el aduar africano). Así, desincentivaba las confusiones y las mezclas.

63 Para un sofisticado análisis sobre esas figuras de la otredad, véase Richard Kearney, Strangers, Gods and Monsters. Interpreting otherness, New York, Routledge, 2003. 
raza, hijos de una nación en que el derecho, la justicia, el fallo, tienen garganta i voz". Estas víctimas gratuitas certifican la precariedad de la identidad civilizada de los chilenos en la mirada de esos extranjeros (un norteamericano y dos ingleses) investidos del valor original de la civilización. Debido al trato recibido, conjetura Vicuña Mackenna, los extranjeros murieron mirando a "aquellos asesinos con ojos de insondable reproche i maldición", suponiendo "que no era entre los cristianos de Punta Arenas sino entre los caníbales de la opuesta costa donde a esa hora se encontraban". El "reproche eterno" lanzado por una de las víctimas a sus fusileros, justo antes de morir, es extensible a todos los chilenos ${ }^{64}$. Ese juicio tiene un peso lapidario, desde el momento en que es atribuido a un inglés, árbitro casi universal del valor humano a ojos de un chileno inseguro incluso de su desmedrada posición en la jerarquía de las identidades nacionales. En potencia, según la inferencia de ese veredicto, entre los chilenos y los "salvajes", no había ninguna diferencia sustantiva.

\section{CONCLUSIONES}

Tradicionalmente, Vicuña Mackenna ha sido considerado como un historiador de la escuela liberal, como un par, en cuanto a adscripción política, de Diego Barros Arana y de Miguel Luis Amunátegui. Esta visión supone que sus textos históricos reflejan su identidad liberal, actuando como cajas de resonancia, más o menos estridentes, de los principios de ese credo político. De hecho el historiador Allen Woll, estudiando los usos de la historiografía chilena en el siglo XIX, concluyó que las pasiones políticas desviaron a los historiadores locales del sano apego al sobrio magisterio objetivista de Andrés Bello, quien, en la década de 1840, enunció un discurso del método luego promovido desde la plataforma institucional de la Universidad de Chile.

En este artículo se propone una lectura distinta. Los textos históricos de Vicuña Mackenna no solo reflejan su identidad pública; también dan cuenta del esfuerzo por construirla y preservarla como una instancia dispensadora de legitimidad política al interior del propio campo liberal. No basta con atender al cuadro de conflictos por la hegemonía cultural entre los adeptos del laicismo y los apóstoles ultramontanos; además, hace falta evaluar la diversidad existente en el seno del liberalismo, considerando que la pertenencia o la exclusión del gobierno, el control o la carencia de los poderes de intervención electoral del Ejecutivo, implicó intentos por trazar formas distintas de identidad liberal. Ante quienes adujeron como bandera de lucha la oposición a la influencia del clero y la promoción de una agenda secularizadora sin desechar el intervencionismo electoral, Vicuña Mackenna postuló un liberalismo contrario a la sustracción de la soberanía popular, vicio

64 Vicuña Mackenna, Cambiaso, 135-136. Este múltiple esfuerzo de rehabilitación que es Cambiaso, tiene, entonces, destinatarios de varias nacionalidades. El autor confía en que el libro será leído en Europa, en donde el monstruo de Magallanes alienta, dice, una "leyenda popular" muy activa. 
de representatividad política que aquejaba gravemente, a su juicio, a la salud institucional de la república.

Como se ha intentado mostrar, los motivos de Vicuña Mackenna para sostener esa postura minoritaria combinan las desilusiones del presente con la articulación de una tradición de rebeldía cívica de la cual deseaba convertirse en custodio y vocero autorizado, a fin de recuperar una posición ventajosa de interpelación política a la opinión pública. Como custodio de ese tesoro, asumió la tarea de recuperar y depurar las tradiciones liberales tenidas por legítimas y, por extensión, anular toda asociación nociva que amenazara con devaluar ese disputado capital simbólico.

Los girondinos chilenos (1876) y la Historia de la jornada del 20 de abril de 1851 (1878) se entroncan con una línea de trabajo iniciada en la década de 1850, al calor de la lucha opositora y de las guerras civiles, cuyo primer hito historiográfico fueron los cinco volúmenes de la Historia de los diez años de la administración de don Manuel Montt (1862-63). Los Lisperguer y la Quintrala. Doña Catalina de los Ríos (1877) intentó rastrear una persistente patología social; al identificar la elección de Aníbal Pinto con un síntoma de su reactivación contemporánea, lanzaba una interdicción ética contra los líderes de la Alianza Liberal que pretendían monopolizar la identidad liberal desconociendo, no obstante, el sentido de sus luchas históricas, las únicas avaladas por un martirologio compuesto de muertos en los campos de batalla y de opositores desterrados. La biografía del otro monstruo, Cambiaso (1877), venía a complementar lo anterior, expurgando la causa de la libertad electoral de cualquier extravío que ensombreciera la nobleza original de sus reivindicaciones. 